fashion, there is in every instance a failure to cite the exact reference. While it is interesting to have monetary changes brought into causal relationship with economic, industrial and political development, one gets the impression that our author gives, at times, undue weight to the influence of those changes.

\title{
Haverford College.
}

Don C. Barrett.

Forman, s. E. The American Republic. Pp. xviii, 359. Price, \$1.10. New York: Century Company, rgir.

This is a textbook in civics, intended especially for use in high schools, academies and normal schools, and is an abridgment of the author's earlier "Advanced Civics." The plan of the larger book has been retained. Part I is a general treatment of the nature of the state and of government, of democracy, liberty, representation, federalism, political partics and the separation of powers. Part II deals with the organization of American government, considering the national, commonwealth, and local government in order. Part III considers the functions of government, international, commercial, financial, public welfare, etc.

The treatment is accurate, clear, and up-to-date; but the space allotted to municipal government and problems seems inadequate, the discussion of government activities will scarcely give immature students a clear conception of the division of function among federal, commonwealth, and local agents, and the two-page outline of party history (pp. 6o-6r) should either be expanded or omitted. A more fundamental objection may be urged against the general plan of the volume. For advanced students a preliminary survey of general political theory may properly precede the specific study of actual government, but beginners are likely to be confused by the eighty-four pages of "essential principles" with which the author introduces his subject. The experience of the reviewer leads him to believe that students should have, some knowledge of the concrete facts of actual government before they are ready for broad generalizations. The book would be better adapted to the purpose intended if the author had narrowed the field rather than condensed the treatment of his earlier volume. As it is, too many topics are discussed too briefly.

Trinity College.

Raymond Garfield GetTeli.

Groat, George G. Attitude of American Courts in Labor Cases. Pp. ix, 400. Price, \$3.00. New York: Columbia University, I9II.

This volume is a contribution to the discussion of the labor question from the standpoint of a sociologist, the material used being the opinions of the courts in their consideration of questions of the organized activities of workmen and of legislative regulation of the conditions of employment. An avowed purpose of the author is to present contrasting opinions, which is effectively done; a 